\title{
Expanding educational access in Eastern Turkey: A new initiative
}

\author{
John O'Dwyer ${ }^{\mathrm{a}}$, Necmi Aksit ${ }^{\mathrm{b}, *}$, Margaret Sands ${ }^{\mathrm{b}}$ \\ a School of English Language, Bilkent University, 06800 Bilkent, Ankara, Turkey \\ ${ }^{\mathrm{b}}$ Graduate School of Education, Bilkent University, 06800 Bilkent, Ankara, Turkey
}

\section{A R T I C L E I N F O}

\section{Keywords:}

Student selection

Educational access

Gender equity

Family characteristics

International education

\begin{abstract}
A B S T R A C T
The Eastern Anatolian project extends opportunity and access to quality education. The study examines the selection and learning systems adopted within the framework of gender equity, family background and higher order skills. Performance data on a range of selection measures and the initial programme are analysed. Results show that selection was successful in choosing high achievers and establishing equitable occupational and gender access. Girls out-performed boys in skills-based selection measures, showed greater relative gains in language learning, and evinced better higher order skills, reversing the trend in state examinations.
\end{abstract}

(c) 2009 Elsevier Ltd. All rights reserved.

\section{Background}

\subsection{Education in Turkey}

Turkey has a population of 73 million, about $29 \%$ of which is under 15 years old. Some 11 million students receive eight-year compulsory primary education. Secondary education, which lasts four years (Grades 9-12), is not yet compulsory, but has more than three million students in general, vocational, or technical high schools (TÜiK, 2007). Entry into tertiary education is highly competitive. In 2007 , some 1.58 million candidates competed in the national university entrance examination (ÖSS) for about 413,000 tertiary sector places. 204,734 of these places were in four-year degree programmes, and 208,413 in two-year programs. The combined gross enrolment ratio for the primary, secondary and tertiary sectors is $68.7 \%$ (UNDP, 2008), with a male-female ratio of 73-64\%.

School dropout rate in Turkey is high after completion of the eight grades of compulsory primary education. $66 \%$ of the boys and $72 \%$ of the girls ( $69 \%$ total) leave school, and only $31 \%$ of those who complete primary school go on to complete high school education. The limited number of tertiary sector places means that only about two-thirds of these $(63 \%)$ are able to apply for tertiary education (TÜIK, 2007). Dropout at the end of primary school is higher in the eastern parts of Turkey and there is increasing gender inequality in education from west to east of the country (see Section 1.3.2).

In 1999 Turkey was granted candidate country status in its bid to join the European Union (EU) and is committed to full EU

\footnotetext{
* Corresponding author. Tel.: +90 312290 2950; fax: +90 3122664065. E-mail addresses: johnbod@bilkent.edu.tr (J. O’Dwyer), necmi@bilkent.edu.tr (N. Aksit), msands@bilkent.edu.tr (M. Sands).
}

membership. Central to the EU's policy of economic development and social cohesion is the quality of education and training. Total public and private expenditure on education in Turkey, as a proportion of GDP, was $7 \%$ in 2002 . This was higher than the Organisation for Economic Co-operation and Development (OECD) average of $5.2 \%$, but provision of quality education across the country still remains a major challenge (Eurostat, 2007; UNDP, 2008; World Bank, 2005; OECD, 2003). The Programme for International Student Assessment (PISA), an internationally standardised benchmarking assessment tool developed by participating countries (OECD, 2008), allows for the monitoring of the outcomes of education systems within an internationally accepted common framework. It focuses specifically on how well 15-yearolds are able to use their knowledge and skills to meet the challenges of real life, rather than how well they have mastered a specific school curriculum (OECD, 2008). The 2003 and 2006 PISA results for Turkey reported an overall poor level of performance, penultimate in the OECD rankings, with a high percentage of low scoring students in most areas tested, viz. mathematics, reading and science (OECD, 2008; PISA, 2004, 2007; Aksit, 2007).

Some educational challenges stem from inequality in income distribution. In 2002 , the richest $10 \%$ of the population earned $30 \%$ of the country's income. The poorest $10 \%$ earned only $2 \%$ (UNDP, 2003). There are regional variations and inequalities, too. The west of the country is a lot more developed than the east. For example, Gross Domestic Product (GDP) in Istanbul, a western city, was $\$ 31,378^{1}$ in 2001 . In the eastern cities of Erzurum and Bingöl it was $\$ 1006$ (see footnote 1 ) and $\$ 202$ (see footnote 1 ) respectively (TÜIK, 2001). This inequality has serious repercussions on the

\footnotetext{
${ }^{1}$ Millions of US dollar.
} 
provision of education in poorer regions. It is also a contributory factor in the migration of families to western parts, which places a heavy burden on educational facilities there.

Education has undergone many changes in recent years. A new national curriculum was launched in 2005 for Grades $1-5$. That for Grades $6-8$ is almost ready. A new four-year high school curriculum is expected soon. The revised curriculum places emphasis on a constructivist approach through instructional methods which encourage discovery and experiential learning. New textbooks are designed to help teachers understand and implement the new philosophy, outlining standards, activities, exercises and assessment strategies.

There is also change in higher education with universities adapting to the European credit transfer system to foster mobility as part of the Bologna initiative. Substantial investment, supported by World Bank funding, has been made in the vocational training sector (World Bank, 2006). Recognition of the need to update teacher training resulted in the revision of teacher education in faculties of education in 1999 (Grossman and Sands, 2008), and a project in relation to language learning has prompted further World Bank funding in 2008.

Turkey has thus made educational progress on many fronts as a candidate country for the EU. However, the PISA results (PISA, 2004, 2007; Aksit, 2007) indicate the need for further reform. The EU Commission 2006 Turkey Progress Report points out that Turkey needs to continue to develop its system of education in line with the Lisbon Strategy to facilitate economic and social integration with Europe (Commission of the European Communities, 2006).

\subsection{Education in Erzurum}

An Eastern Anatolian Project, initiated by a Turkish university, offers one such means to develop education in Turkey. The project aims to establish four K-12 schools in four cities in the eastern region of the country, following a combined international and national curriculum. The first high school was opened in 2007 in Erzurum, recruiting some 80 students, most of whom are on full scholarship. It comprises a preparatory year for English language learning, followed by Grades 9-12. A law in parliament was enacted to legitimise the initiative.

Situated on the northern slopes of the Palandoken mountain at an elevation of $1850 \mathrm{~m}$ Erzurum, with a land area of $25,066 \mathrm{~km}^{2}$, is the largest city in the Eastern Anatolian Region of Turkey. The population of the city as per the census of 2008 is 784,941 . About $60 \%$ of the population lives in the urban area, and the rest in rural areas. For rural families, farming, forestry and livestock breeding are among the main sources of income. Atatürk University, one of the largest universities in Turkey, with about 35,000 students and staff, provides a large proportion of the city's revenue.

In Erzurum, there are 1070 primary schools with some 142,000 students, and 86 secondary schools with about 29,000 students (Table 1). The total number of primary and secondary students enrolled in both public and private schools in Erzurum constitutes $1.3 \%$ of the students receiving public and private education in Turkey.

Many schools in the Eastern Anatolian Region lack basic infrastructure, and more schools are needed to meet the needs of the area. The average attendance at school in the Easter Anatolian Region is 4.1 years (Eğitim Sen, 2005, as cited in Aksoy, 2008). About $20 \%$ of primary school students are educated in multi-grade classes (Milliyet, 2007; MEB, 2003). Multi-grade schooling, mainly at the primary school level, is implemented widely in the eastern regions of Turkey (Aksoy, 2008). Sanlıurfa has the highest number, with 914 multi-grade schools, and Erzurum with 810 schools is ranked 2nd (Radikal, 2007). It is estimated that about 2800 more
Table 1

Schools and students.

\begin{tabular}{|c|c|c|c|c|}
\hline & \multicolumn{2}{|c|}{ Number of schools } & \multicolumn{2}{|c|}{ Number of students } \\
\hline & Erzurum & Turkey & Erzurum & Turkey \\
\hline \multicolumn{5}{|c|}{ Primary school } \\
\hline Public & 1,066 & 33,227 & 141,107 & $10,644,383$ \\
\hline Private & 4 & 866 & 821 & 226,187 \\
\hline \multicolumn{5}{|c|}{ Secondary school (general) } \\
\hline Public & 84 & 3,119 & 28,369 & $1,887,625$ \\
\hline Private & 2 & 711 & 341 & 92,827 \\
\hline Total & 1,156 & 37,923 & 170,638 & $12,851,022$ \\
\hline
\end{tabular}

TÜIK (2007).

teachers and 1075 more classrooms are needed to educate the children in Erzurum (Erzurum Gazetesi, 2008).

Turkey has the most highly centralised education system of any OECD member state (Fretwell and Wheeler, 2001), and school education is characterised by a high degree of centralised control. The Ministry of National Education (MONE) makes most policy decisions including finances, infrastructure, staff, curricula, textbooks, equipment, and number of students. According to OECD data, about $94 \%$ of all education decisions in Turkey are currently made at the central level. The central system aims to bring about equity in the school system, but significant disparities still exist nationwide (World Bank, 2005).

The Eastern Anatolian project mentioned at the start of this section is unique in that it is implemented within the framework of a centralised education system. It offers bilingual national and international curricula to the students living in Erzurum where there is limited access to quality education. At high school level, the project intends to meet the requirements of the national curriculum as laid down by the ministry, as well as those of the international curriculum, which comprises IGCSE and IB. In grades 9 and 10, all students will follow a two-year internationally accredited IGCSE programme, and in grades 11 and 12, the IB diploma programme. Both IGCSE and IB programmes enhance the ministry's new curriculum based on constructivist principles.

In other countries around the world there are school reform movements. Most are government-initiated projects allowing interested parties to apply for funding. For example, the comprehensive school reform (CSR) program in the US, which started in 1998, allows federal funds to be allocated to schools, mainly in high poverty areas, uniting state and local efforts for higher standards and school improvement (US Department of Education, 2002, 2009). Investing in Our Schools programme in Australia funds infrastructure projects such as construction, installation or procurement, and intends to address the priorities identified by government and nongovernment school communities in conjunction with school principals (AGDE, 2009). In the UK, Academies are all-ability state-funded schools, set up and managed from 2002 by sponsors from the world of education and business. In 2009, there are 133 Academies across the country and government is committed to establishing at least 400 (DCFS, 2009a).

Using Brint's (2006) classification of school reforms, the Eastern Anatolian project aims are centered on excellence, enhancement and equity. The project aims to raise standards of excellence, to enhance the whole development of students, and to improve equity by offering quality opportunities to students living in those regions.

\subsection{SES and gender related to achievement in school}

\subsubsection{Socio-economic status}

Many studies have investigated the relationship between socioeconomic status (SES) and school achievement. In the UK, an early, and well-known, longitudinal study was the extensive work of 
Douglas and his colleagues who followed the progress of 5302 children born in the UK in the first week of March 1964 from birth (Douglas, 1964; Douglas et al., 1968). In the US, the Coleman Report considered the findings of a research project involving 600,000 children in 4000 schools (Coleman et al., 1966).

The trend of all such earlier studies underlined the importance of the home and family background in educational attitudes and achievement by students in school. Douglas reported, 'social background has a persisting influence in secondary school performance'. Children from families of higher SES were generally more successful in school, and more represented in post-school education (Douglas et al., 1968, p. 179).

Halsey et al. (1980), however, sounded a cautionary note when they said that student performance was not largely accounted for by socio-economic background, and that the allocation of students to different parts of the school system was largely based on ability.

Later researchers also urged caution in the interpretation of research work. White (1982) criticised the overview generally held, that the higher the family SES the higher the student's academic performance, as summarised in Boocock (1972). White goes on to report that the relation between SES and academic achievement was probably much weaker than many people had assumed.

White used meta-analysis techniques to examine in detail 101 studies which dealt with the relationship between SES and academic achievement. He reported that if SES was defined, as was usual, as income, parental occupation and/or education, and if the study used individual students as the unit of analysis, then SES had only a relatively low correlation with academic achievement (White, 1982). He pointed out that the actual definition of SES used is of the utmost importance in relating academic achievement to SES, as also are the measures used to determine achievement.

Sirin replicated White's meta-analysis with an analysis which included the journal literature on the topic between 1990 and 2000: 58 published articles. Sirin concluded that the relationship between SES and school achievement was not as strong as even that reported by White 20 years earlier. Sirin's results showed a slight decrease in the average correlation: whereas White's overall mean correlation was .343 for the published journal articles he included, Sirin's was .299 (Sirin, 2005).

Sirin suggested that the way in which the definition of SES had developed to include more indicators, as well as how achievement was measured, and student characteristics recorded and evaluated, may have affected results. The field is complex. SES is a multidimensional construct, which extends beyond parental occupation, education and income to include such items as home resources, social capital, cultural capital, wealth, power, social status which may not be separated out in a research study. Further, a lower correlation over the years may be due not only to changes in research methodology but also to the many changes in economic and social life in recent decades (Sirin, 2005).

Both Sirin and White used studies done in the US. NonoyamaTarumi (2008) in an analysis of SES relating to the 2000 PISA results from 30 countries (OECD, 2001, 2002) concludes that family background has a stronger effect on achievement across countries if a multi-dimensional measure is used rather than more basic indicators of SES. A further study using the international PISA data from 2000 looked at the between- and within-school differences in student achievement in relation to their socio-economic background and home resources (Marks, 2006). Marks concluded that such differences could be accounted for only partially by SES, and that his study (like that of Halsey in 1980) supported the view that student ability is largely responsible for allocation to different types of school.

The study reported in the present paper concerns the selection of students for high school at the end of grade 8 , aged 14 . Smits and
Hoşgör (2006) in research on Turkey into the effects of family background on educational participation concluded that parental education, occupation and income had positive effects on their children's attendance and progress in school.

In considering children living in the east and southeast of Turkey and in the countryside, Smits and Hoşgör reported that many women had not attended or completed primary school, and considered how the education of their children may have been affected. They concluded that a number of factors added up to significant inhibitors of children's participation and achievement in school. The factors included low maternal education, early marriage, mother speaking a language other than Turkish, low family income, more than four siblings, and living in the east and in the countryside.

The school set up in Erzurum is a contribution to quality education in the Eastern Region of Turkey. The techniques used in selecting students for the school were developed to give opportunities to children from families in all walks of life, and equally to boys and girls.

\subsubsection{Gender}

Although in the last 25 years the educational performance of both boys and girls has improved (Ward, 2004), since the middle of the 1990s the emphasis of discussion has shifted from the earlier underachievement of girls to that of boys. Concern for the fact that boys seem to be falling behind has been expressed in a number of countries: UK, other EU countries, Canada, USA, Australia and New Zealand (Forde, 2008).

In the UK, for example, when success in examinations in GCSE subjects is considered, $69.9 \%$ of girls achieved five or more grades $\mathrm{A}-\mathrm{C}$, and $60.9 \%$ of boys, and a gender gap is also seen at all three Key Stages below GCSE (DCFS, 2009b). Girls now get higher grades on average than boys in most subjects throughout secondary education in England. Previously, boys did better at mathematics, but girls seem to have caught up. Girls always did better on average than boys in English, and the girls are doing even better now, and there has been much discussion as to the causes of this gap, and policy changes to deal with it (Arnot et al., 1998; Machin and McNally, 2006).

From OECD countries, the PISA research notes a gender gap in the attainment of 15-year-old students in school: in 39 of the 40 countries included, girls had a significantly higher average performance in reading than boys. On the other hand, boys achieved better scores than girls in mathematics in most countries (OECD, 2004). Other studies have also shown that girls perform better than boys for all main school subjects (Steinmayr and Spinath, 2008; Epstein et al., 1998; Wong et al., 2002).

The gender gap has widened more in secondary than in primary school in recent years, and cannot be explained by considering the differences between schools (Machin and McNally, 2006). It seems that the start of the gender gap effect in England was at about the time when the 16-plus school-leaving examination system changed from O-levels to GCSEs. Machin and McNally argue that the increased coursework in the GCSE may be a contributory factor in accounting for the gender gap at age 16, as also may be the 'gender differential in skills that are rewarded by assessment in GCSE'. Coursework is work, largely written work, by students which is assessed by teachers.

Many research studies show that coursework is important in the differential performance of boys and girls, and it follows that how students are assessed influences the relative performance of boys and girls. Studies show that girls do better with essays and coursework, and boys with multiple-choice questions (Powney, 1996; Stobart et al., 1992; Elwood, 2005). Gipps and Murphy (1994) summarised research from a number of countries which showed that the performance of boys improves relative to girls when multiple-choice tests are used. 
Table 2

Percentage not in education of all Turkish girls and boys aged 9-11 and 13-14 in 1998 by geographic region.

\begin{tabular}{lrrrrr}
\hline Region & \multicolumn{2}{c}{ Age 9-11 } & & & Age 13-14 \\
\cline { 2 - 3 } \cline { 5 - 6 } & Girls & Boys & & Girls & Boys \\
\hline West & 4.3 & 1.7 & 37.2 & 26.5 \\
South & 15.3 & 6.1 & 51.9 & 33.0 \\
Central & 8.5 & 4.6 & & 45.8 & 29.0 \\
North & 1.7 & 2.4 & & 50.8 & 24.6 \\
East & 35.5 & 16.4 & 74.3 & 40.2 \\
\hline
\end{tabular}

From Table 3, Smits and Hoşgör (2006).

On the other hand, Tinklin (2003) offers personality differences between girls and boys, attitudes and peer group pressures as explanations to these differences. She also suggests that many other issues such as teaching and learning techniques, the content and assessment of the curriculum, teacher-pupil interactions, as well as cultural and economic factors including the attitudes of parents, employment opportunities and after-school training, should be considered when attempting to define gender differences in performance at school. Steinmayr and Spinath (2008) also consider sex differences in achievement motivation.

A discussion on gender differences in achievement in schools in the eastern and southeastern regions of Turkey begins in a different place. The UNESCO (2003) report on gender and education for all gives Turkey as one of the twelve countries, from amongst 128, which was 'not expected to reach either the primary or secondary education goals of gender parity by 2015' (UNESCO, 2003).

In Turkey, there are gender differences in participation in primary education (Grades 1-8) and even greater differences in secondary education (Grades 9-12), with the boys having the advantage of an earlier and longer school life. The number of children who do not attend school is high, particularly at secondary level (Aytaç and Rankin, 2004). In 2006, the net primary school enrolment for the whole of Turkey was $90.1 \%$ of the age group ( $92.3 \%$ boys and $87.9 \%$ girls). The net secondary school enrolment was $56.5 \%$ ( 60.7 boys, 52.2 girls) (TÜiK, 2008).

The gender differences become wider in some parts of the country, notably in the east of the country. Table 2 shows the tremendous gap between the western and eastern regions of Turkey, and between boys and girls in the east, at both ages (Smits and Hoşgör, 2006).

Smits and Hoşgör (2006) point to a number of factors which influence the non-attendance of girls at school. Not surprisingly, they are similar to those given earlier for SES and include the educational level of both parents, low family income, language spoken by mother, the occupation of the father and if the mother works, number of siblings, if mother married younger than 17 years, traditional gender role attitudes in the family and especially of mother, and living in country or town.

This paper gives later the number of boys and girls who applied to, and achieved success in, the entrance examinations to the Erzurum school; and their progress in their early education in the school. Bearing in mind the data given above, it can be seen that the girls did well to achieve such success. The types of assessment used which moved away from multiple-choice questions and included other means of assessment may have contributed to their success.

\section{Vision and objectives of the eastern initiative}

The university which set up the Eastern schools initiative has several schools on its campus. They include IGCSE and IB programmes, and a music conservatory for gifted young musicians. These achievements represent good credentials on which to launch the Eastern school initiative.
One of the main aims of the new school in Erzurum is to establish access in the area to high quality education which emphasises the development of higher order skills, with a view to preparing students for higher education, as well as providing needed skills for the market. The current university selection examination in Turkey consists largely of multiple-choice questions favouring rote memorisation (World Bank, 2005; Şahin, 2004).

Teaching to this highly competitive examination does not allow the development of critical thinking skills which the government is targeting along with other skills (Talim Terbiye Kurulu, 2005). The educational aims of the Erzurum school are promoted through preparing students for the internationally recognised qualifications mentioned in Section 1.2.

A second aim of the school is to contribute to the development of the community in which it is situated. The school regulations, approved by the ministry, support the integration of the family within their child's education by requiring, for example, families to keep up with their child's progress by attending regular meetings with the senior staff. The family is thus given due weight as a key stakeholder in the educational process and is expected to participate.

In addition, by making the school a centre for cultural events such as concerts, exhibitions and conferences a wider audience within the community is sought, initially through children and their families, but extending outwards. The project also aims to give back to the community by rendering service, in the short term through requiring students to seek involvement in community projects as part of their study, and in the longer term by encouraging them to return to the area after completing university.

A third aim is to provide an education on a par with that available in the richer parts of Turkey to help to reduce inequalities of opportunity. It is hoped to keep high-achieving students within the area, to attract other skill-bearing families who might otherwise not come, and spread a different model of education.

A fourth aim is to include a mixture of students from different social backgrounds in one establishment. Selection is based on merit established through a wider range of indicators than is customary in the examination for the competitive high-end state schools. The expectation is to gather, from different family backgrounds, students who show promise on the assessment of critical thinking, knowledge, aptitude, and communication skills. The provision of up to $90 \%$ full scholarships means that no child should be excluded because the family cannot afford to pay.

A fifth aim of the project is to teach English language skills so as to provide students with access to the international qualifications targeted by the school. Encompassed within this aim is the fostering of international mindedness included, for example, in the philosophy of the International Baccalaureate, which promotes its vision beyond the confines of single communities and opens a window on the world for tolerance and understanding.

\section{Method}

\subsection{Research aims and data collection}

The research reported here sets out to investigate the extent to which the Eastern Anatolian Project is achieving its goals. The specific aims were four-fold: to describe the performance and profile of the recruits attracted by the selection process; to gather data on the training program and the value added to specific language and broader learning skills; to guide formative learning and development founded on systematic collection, analysis and use of evaluation data (O'Dwyer, 2008); and to provide guidance to future educational initiatives in challenging locations, economic or geographical. 
The researchers built into the project selection process a mainly quantitative approach to performance data collection and analysis, for comparative purposes. Tests external to the project were adopted with a view to providing robust, project-independent measures of ability, having been trialled in three institutions of the university specialising in the areas tested, viz. English language, school subjects, and music. Interview data was gathered after interlocutors were trained and standardised on the criteria to be used. General and gender performance was investigated through comparing dichotomised, quantitative, test data collected during selection: four separate measures during Stage 1 of the selection process (tests of aptitude, mathematics, science, and Turkish); three separate measures during Stage 2 (interview, composition, musical aptitude). In addition, for comparison, scores for each Stage 2 student were obtained for performance on the mainly multiple-choice government high school entrance exam, OKS. Overall and relative performance on language was measured through placement, mid-course, and final exams, all previously administered in other contexts.

In addition to test data to compare performance, a 29-item Likert scale questionnaire was completed by all teachers to investigate students' learning skills under five headings, based on student performance during their first seven-week course. The quantified Likert scale data were averaged, as well as dichotomised for gender. All performance data were submitted to analysis using standard statistical analysis as well as tests of significance (ANOVA and factor analysis) using a software package (SPSS). Internal validity was enhanced through: the use of project independent measures of ability; the training and standardisation of examiners; and the triangulation of perception data through multiple questionnaires for individual students.

In order to explore the extent to which the project permitted a broad range of socio-economic access, the study categorised fathers' occupation for all families from a questionnaire given at application. Occupational data for mothers was also quantified for potential impact on selection outcomes.

The research takes the form of the preliminary stages of a case study, common in organisational studies (Gummesson, 2000) for studying contemporary events with a view to explaining complex social phenomena (Yin, 1994). According to Orum et al. (1991), case studies reflect natural settings, are holistic studies, focus on continuity and change, and contribute to theoretical generalisation. This characterisation applies to the current study which is restricted to a particular instance, serves a revelatory purpose, and has more than one unit of embedded analysis (Freebody, 2003). Particular attention is accorded to quantitative and qualitative data as part of both a corroborative and complementary strategy (Brannen, 2004). The replication of the selection process for successive cohorts of entering students will contribute to generalisability of conclusions, hence external validity.

This initial study reports, in the main, on the first three aims cited above. Longer-term patterns are to be the object of further studies.

\subsection{The student selection process}

The project constitutes a major educational investment, in a new direction, for the eastern regions of Turkey. Student progress is being monitored. The data collected and results given in this paper represent an early stage of the monitoring process. The main areas of interest here, then, are issues surrounding the selection process and the early orientation of students to the new system, including their adoption of the skill profile intended in the program.

A minimum grade point average (GPA) of 4.2 out of 5 for Grade 8 graduation was required for candidates to enter for the examina- tions for the Erzurum school. Although reliability of primary school assessment grades is not guaranteed, this barrier was set to discourage non-performers. 867 students applied. A two-stage selection process for candidates was developed.

The first stage, an elimination process, required the development of a test specification which would reflect students' readiness to undertake the kind of learning that the school promotes. The validity concern was to devise instruments to measure congruence between the aims of the school and desired candidate traits. The written examination moved away from multiple-choice questions, which make up selection examinations in the national system, to a focus on short and longer answers targeting higher level thinking skills.

The test instruments assessed students' knowledge in core subject areas of the national curriculum studied up to the end of Grade 8 and their ability to think. Questions were devised by expert staff to reflect standards already established by one of the schools of the university and used to select scholarship students to that school. The papers were marked by a team of experienced graders, after standardised marking of a sample of scripts.

In addition, a commercially available standardised aptitude test was used to give an opportunity to students with potential but whose previous education might not have prepared them for the curriculum outcomes targeted in the short-answer test. The aptitude test scoring was machine marked, with outcomes adjusted for age. The number of students selected after the first battery of tests was 221.

The second stage submitted those selected to an oral examination in three parts. Firstly, an essay to be written in Turkish was set and marked independently to a standard. Secondly, candidates talked to a panel of teachers on topics chosen from a selection available, as well as their essay. Teachers graded independently on agreed criteria and the scores were averaged to give a single grade. Thirdly, candidates took a test of musical aptitude, administered by a musician from the Faculty of Music. It assessed students on their practical ability to recognise and reproduce in response to musical stimuli.

The number of students chosen from the second stage was $\mathbf{1 2 4}$.

In addition to assessment data from the selection process, background data on each candidate was collected. It included personal details, school averages for Grades 4-8, national scores on examinations for high school entrance taken at the end of Grade 8 (for Stage 2 candidates), the profession of parents, and if families would enrol without a scholarship.

\subsection{Method of assessment at the summer school}

In view of the high academic objectives set, an eight-week summer school was provided to give intensive English training before starting at Erzurum in the newly built high school. Students also had music, science, mathematics and Turkish lessons.

The summer programme took place on the university campus and was staffed by experienced native and non-native teachers of English from institutions of the university. An elaborate system of supervisors was set up to monitor and support students during their stay in a university hall of residence. Students also participated in a social activity programme and began to experience the wider objectives of the Erzurum initiative. Students' parents were invited at a weekend mid-point in the programme to meet the programme sponsors and staff.

At the start, most students had low English language skills, averaging $33 \%$ on a placement test, only two students scoring above $50 \%$. Yet within one year they had to be proficient enough to follow IGCSE courses, covering six subjects. Within three years, they would sit IGCSE examinations. 
Students were placed in classes based on their English placement test scores. English language performance data was obtained from mid-term exams (weighted 40\%) and final exams (weighted 55\%) in the following areas: listening and reading; grammar and vocabulary; and writing. The remaining $5 \%$ was allocated by the class teachers as part of a teacher assessment grade.

One aim of the project, as outlined in Section 2, is to develop higher order thinking skills in line with a constructivist perspective on education, as part of educating well-rounded individuals. With the aim of getting data on the learning and study skills of the Erzurum students, a 29-item questionnaire was devised and administered during the summer school. It asked teachers and supervisors, towards the end of the summer programme, to assess student performance under six major skills headings: interpersonal skills; research skills; communication skills; thinking skills; classroom related self-management skills; wider school related self-management skills.

The questionnaire reflected the skill profile used by the International Baccalaureate for its Primary Years Programme (PYP, 2008) and represented a desirable set of characteristics for the end of Grade 8. Each major heading was broken down into sub-skill items, with an explanation for each item to facilitate standardisation. Each item required a Likert-type scale response, from 1 to 4 .

\section{Results}

\subsection{Results of assessment stages from application to final selection}

A first cohort of 867 students applied within the criteria and time limits set. Test centres were established in Erzurum, Istanbul and Ankara. The data collected during the Stage 1 assessment were individual and aggregate scores in the subject tests (mathematics, science, Turkish); along with a single aptitude score reflecting the candidate's age profile. Only $14 \%$ of applicants stated that they would be able to pay fees if offered a place.

The following decision rule operated for selection from the Stage 1 assessment, with number of students selected for each test (in brackets): an aggregate score above $70 \%$ in the subject areas tested (18); or above a benchmark score in aptitude, with a minimum of $60 \%$ in the subject areas (195); or above a high benchmark score in aptitude only (8). The test discriminated well for the purposes of the project and 221 students, approximately $25 \%$ of applicants, were selected for Stage 2 . Five more were added as children of teachers.

The selection from Stage 2 was based on the average score across the three elements of the second assessment exercise: individual essay, interview, and musical aptitude, but also took into account the results of Stage 1. Candidates with an overall score of over $70 \%$ across the five areas of the two Stages were selected. All individual grades below 70\% were scrutinised and students who, despite a low score on one or two of the five indicators, showed promise in others were added.

A breakdown of the average percentage aggregate scores for all candidates is given in Table 3 for Stages 1 and 2. These are the average scores for those who progressed to the next level of selection. It permits a picture of the candidate profiles through the stages in terms of the instruments employed. Table 3 also separates for gender.

Two further data sets have been added to Table 3 . The first assessment gives aggregate scores of the points obtained in the national high school selection exam (OKS) by those candidates offered a place in the Erzurum high school. The OKS is a multiplechoice format test taken just after Stage 2, assessing students on core subjects studied in Grades 6-8 (Șhin, 2004; Yurdugül and Așkar, 2004). It ranks students nationally for places in prestigious high schools, with a maximum obtainable score of 500 . The second extra data set gives average scores on a study skills questionnaire completed by teachers for students selected for Erzurum who completed the summer school.

Table 3 shows a satisfactory selection process with successive elimination of those who were low performers in Stage 1, particularly in the subject areas tested, with an overall increase of $19 \%$ in group averages (52-71\%), and also with an increase in aptitude of $8 \%(66-74 \%)$.

\subsection{Results of the selection process analysed by gender}

Table 3 shows an almost equal number of male (51\%) and female (49\%) applicants for Stage 1, with a similar distribution

Table 3

Results of assessment from the selection process for Erzurum high school.

\begin{tabular}{|c|c|c|c|c|c|c|c|c|c|c|c|}
\hline & \multirow[t]{2}{*}{ Gender } & \multicolumn{2}{|c|}{ Candidates } & \multicolumn{2}{|l|}{ Stage 1} & \multicolumn{3}{|l|}{ Stage 2} & \multicolumn{2}{|l|}{ OKS } & \multirow{2}{*}{$\begin{array}{l}\text { Skills } \\
\text { (out of 4) }\end{array}$} \\
\hline & & $N$ & $\%$ & $\begin{array}{l}\text { T-M-Sc } \\
\text { (out of } 100 \text { ) }\end{array}$ & $\begin{array}{l}\text { Apt. } \\
\text { (out of 100) }\end{array}$ & $\begin{array}{l}\text { Interview } \\
\text { (out of } 100 \text { ) }\end{array}$ & $\begin{array}{l}\text { Music } \\
\text { (out of 100) }\end{array}$ & $\begin{array}{l}\text { Essay } \\
\text { (out of 100) }\end{array}$ & $\begin{array}{l}\text { T\&M } \\
\text { (out of } 100 \text { ) }\end{array}$ & $\begin{array}{l}\text { Sc\&M } \\
\text { (out of 100) }\end{array}$ & \\
\hline Stage 1 & Total & 867 & & 52 & 66 & - & - & - & - & - & - \\
\hline \multirow{2}{*}{ Took exam } & Girls & 424 & 49 & 51 & 66 & & & & & & \\
\hline & Boys & 443 & 51 & 52 & 66 & & & & & & \\
\hline Stage 2 & Total & 226 & & 68 & 73 & - & - & - & - & - & - \\
\hline \multirow[t]{2}{*}{ Offered Stage 2} & Girls & 117 & 52 & 68 & 74 & & & & & & \\
\hline & Boys & 109 & 48 & 68 & 73 & & & & & & \\
\hline Stage 2 & Total & 207 & & 68 & 73 & 81 & 63 & 59 & - & - & - \\
\hline \multirow[t]{2}{*}{ Took exams } & Girls & 112 & 54 & 68 & 74 & 84 & 64 & 61 & & & \\
\hline & Boys & 95 & 46 & 67 & 73 & 79 & 61 & 58 & & & \\
\hline \multirow[t]{3}{*}{ Places offered } & Total & 124 & & 71 & 74 & 86 & 65 & 65 & - & - & \\
\hline & Girls & 73 & 59 & 70 & 75 & 87 & 67 & 67 & & & \\
\hline & Boys & 51 & 41 & 70 & 73 & 84 & 63 & 63 & & & \\
\hline Registered & Total & 94 & & 71 & 74 & 86 & 65 & 64 & 412 & 405 & \\
\hline \multirow[t]{2}{*}{ Summer programme } & Girls & 55 & 59 & 72 & 75 & 88 & 69 & 66 & 408 & 399 & \\
\hline & Boys & 39 & 41 & 71 & 72 & 83 & 61 & 62 & 419 & 414 & \\
\hline End of summer & Total & 84 & & 71 & 74 & 84 & 65 & 64 & 408 & 401 & 3.21 \\
\hline \multirow[t]{2}{*}{ August 2007} & Girls & 48 & 57 & 71 & 75 & 88 & 69 & 66 & 403 & 394 & 3.30 \\
\hline & Boys & 36 & 43 & 71 & 73 & 82 & 60 & 61 & 416 & 410 & 3.08 \\
\hline
\end{tabular}

T: Turkish; M: mathematics: Sc: science; Apt: aptitude; OKS: the national high school selection examination. 
(male $48 \%$; female $52 \%$ ) for those offered Stage 2 . This does not reflect the high school population in the east of Turkey, which comprise $64 \%$ boys and 36\% girls. This point is pursued in Section 5.1 of the discussion.

After Stage 2, however, the percentage of successful girls increased to $59 \%$. This is an interesting statistic in a part of Turkey associated with a more traditional perspective on female access to education. The expectation was for higher numbers of male applicants and male success. Girls achieved a slight difference in average performance across all three Stage 2 measures. Of those later registered for the summer programme however, girls performed significantly better in both interview (88:83) and music (69:61) averages $(p<.05)$ in Stage 2 , with a clear but not statistically significant advantage in essay scores (66:62) as well. This accounts for the increase in the proportion of girls relative to boys in the number of places offered and uptake, and also supports the point about gender and types of assessment discussed in Section 1.3.2.

Despite gender equivalent, non-significant scores for boys and girls on the English placement test at the start of the summer school, the end of course examinations at the summer school showed statistically significant gains, based on aggregate grades, for girls over boys $(p<.05)$. The outcome is discussed further below in relation to skills data obtained for the same students at the end of the summer program.

\subsection{Results of the selection process related to family background}

The application process for the school asked parents to state their work or profession. Their replies were translated and are summarised in Table 4 . The data remain somewhat imprecise as the researchers had to deal with much overlap in categories, a learning point for future years. Nonetheless, Table 4 shows the numbers, usually fathers, under each of the different groups listed in the raw data, for each of the stages in the selection process. For comparison purposes the percentages for Stage 1 (867 families) and the summer school (84 families) are also given.

To aid discussion, a rough grouping has been made of the different categories. In Table 4, army personnel are grouped together; professionals with a high education level such as university lecturers and lawyers form the next group. The technicians form a group; as do the self-employed, workers, and farmers; and those out of the workforce or with no data.

One category, translated as civil servants with 256 people gives problems in analysis. The Turkish for civil servant (memur) is a very broad category indeed. Many civil servants will classify themselves as memur, without being more specific. Other civil servants prefer to classify themselves by their job, such as teacher. All those who work in government offices, such as (for example) the city and county education offices are classified as civil servants. The executives and middle management personnel there would call themselves civil servants, as also would the assistants, secretaries, even drivers, and messengers. It is clear that this category represents a very broad band of background and, as defined here, includes both low-ranking, poorly paid employees as well as educated people in relatively highly paid positions.

The biggest gains came to those in the second category, mainly university lecturers, which rose from just below 7 to $18 \%$ as a proportion of the total. Percentage-wise the technician group (from 3\% to 6\%) also fared well. The percentage of those from the military remained almost the same $(5.8 \%$ and $6 \%)$, whereas the biggest reduction in the selection process was amongst those in the category of the self-employed, small traders, farmers and workers, who dropped by half from $38.1 \%$ to $17.9 \%$. However, those who called themselves civil servants, representing a broad band of socio-economic families, remained high in both the number of those who applied and those selected, increasing by $7.4 \%$ of the total between the beginning and end of the process.

The figures indicate that a broad socio-economic cross section of families, probably representative of the spectrum in Erzurum, applied to the school. Those whose children were selected after all the tests and interviews also seem to form a cross section of the community.

Working mothers are important in the families in the final selection, relative to Stage 1 . The data show that $46 \%$ of the mothers whose children were selected for the school are working as opposed to only $18 \%$ of the mothers in families who applied to Stage 1. Table 5 gives the percentages of non-employed and

Table 4

Profession of candidates' fathers (taken from application form).

\begin{tabular}{|c|c|c|c|c|c|c|c|}
\hline \multirow[t]{2}{*}{ Father's profession } & \multicolumn{2}{|c|}{ Stage 1} & \multirow{2}{*}{$\begin{array}{l}\text { Stage } 2 \\
N\end{array}$} & \multirow{2}{*}{$\begin{array}{l}\text { Select } \\
N\end{array}$} & \multirow{2}{*}{$\begin{array}{l}\text { Registered } \\
N\end{array}$} & \multicolumn{2}{|c|}{ End of summer } \\
\hline & $N$ & $\%$ & & & & $N$ & $\%$ \\
\hline Non comiss. officer & 38 & 4.4 & 13 & 7 & 3 & 2 & 2.4 \\
\hline Officer & 12 & 1.4 & 6 & 6 & 4 & 3 & 3.6 \\
\hline University lecturer & 58 & 6.7 & 25 & 19 & 16 & 15 & 17.9 \\
\hline Engineer & 17 & 2.0 & 7 & 2 & 1 & 0 & 0 \\
\hline Teacher & 1 & .1 & 1 & 1 & 1 & 0 & 0 \\
\hline Lawyer & 2 & .2 & 1 & 0 & 0 & 0 & 0 \\
\hline Architect & 1 & .1 & 1 & 0 & 0 & 0 & 0 \\
\hline Accountant & 2 & .2 & 1 & 1 & 1 & 1 & 1.2 \\
\hline Biologist & 1 & .1 & 1 & 1 & 1 & 1 & 1.2 \\
\hline Tax Inspector & 1 & .1 & 1 & 1 & 1 & 1 & 1.2 \\
\hline Civil servant & 256 & 29.5 & 76 & 43 & 33 & 31 & 36.9 \\
\hline Technician & 28 & 3.2 & 9 & 6 & 6 & 5 & 6.0 \\
\hline Self-employed & 222 & 25.6 & 39 & 15 & 10 & 10 & 11.9 \\
\hline Worker & 80 & 9.2 & 10 & 6 & 5 & 4 & 4.8 \\
\hline Farmer & 29 & 3.3 & 1 & 1 & 1 & 1 & 1.2 \\
\hline Retired & 92 & 10.6 & 28 & 11 & 7 & 6 & 7.1 \\
\hline Unemployed & 1 & .1 & 0 & 0 & 0 & 0 & 0 \\
\hline Deceased & 20 & 2.3 & 4 & 2 & 2 & 2 & 2.4 \\
\hline No data & 6 & 1.0 & 2 & 2 & 2 & 2 & 2.4 \\
\hline Total & 867 & & 226 & 124 & 94 & 84 & \\
\hline
\end{tabular}


Table 5

Profession of candidates' mothers amongst summer school students.

\begin{tabular}{|c|c|c|c|c|c|}
\hline & \multirow{2}{*}{$\begin{array}{l}\text { Stage } 1 \\
\%\end{array}$} & \multirow{2}{*}{$\begin{array}{l}\text { Stage } 2 \\
\%\end{array}$} & \multirow{2}{*}{$\begin{array}{l}\text { Select } \\
\%\end{array}$} & \multicolumn{2}{|c|}{ Summer } \\
\hline & & & & $\%$ & $N=84$ \\
\hline Non-working mothers & 82 & 67 & 59 & 54 & 45 \\
\hline Working mothers & 18 & 23 & 41 & 46 & 39 \\
\hline Civil servant & & & & & 21 \\
\hline Retired & & & & & 6 \\
\hline Lecturer & & & & & 5 \\
\hline School teacher & & & & & 3 \\
\hline Engineer & & & & & 2 \\
\hline Trader & & & & & 1 \\
\hline Bank employee & & & & & 1 \\
\hline
\end{tabular}

Table 6

A comparison of learning and study skill levels for the Erzurum students.

\begin{tabular}{llll}
\hline Main skill areas & $\begin{array}{l}\text { All students } \\
\text { Mean }\end{array}$ & $\begin{array}{l}\text { Girls } \\
\text { Mean }\end{array}$ & $\begin{array}{l}\text { Boys } \\
\text { Mean }\end{array}$ \\
\hline Interpersonal skills (includes 5 sub-skills) & 3.21 & 3.30 & 3.09 \\
Research skills (includes 8 sub-skills) & 2.97 & 3.06 & 2.83 \\
Communication skills (includes 4 sub-skills) & 3.12 & 3.23 & 2.96 \\
Thinking skills (includes 6 sub-skills) & 2.92 & 3.01 & 2.79 \\
Self-management skills (class) & 3.45 & 3.56 & 3.30 \\
$\quad$ (includes 3 sub-skills) & 3.59 & 3.66 & 3.50 \\
Self-management skills (wider school) & & & \\
$\quad$ (includes 3 sub-skills) & 3.21 & 3.30 & 3.08 \\
$\quad$ Mean & & & \\
\hline
\end{tabular}

employed mothers per stage in the process. From the data it appears that a working mother in the family conferred an advantage to a child in the selection process.

\subsection{Skills assessment of those students who were selected}

The study skills questionnaire was completed by on average seven different teachers and supervisors who had worked with the students during the summer school. The teacher data was retained, supervisor data was not retained as supervisors had spent no class time with the students. This left approximately five sets of questionnaire data per student. The data was averaged to give a single score per student on each of the 29 skill profile items. They were then averaged under main skill headings; and finally averaged across headings to give a single total average skill score for each student, as shown in Table 6.

Table 6 shows that some main skill areas are stronger than others. Weaker areas were those associated with thinking (2.92) and research skills (2.97), two key pillars in a constructivist paradigm. Students were revealed as less performing in the thinking skills of synthesis, analysis, dialectical thought and metacognition; and in the research skills of formulating questions, organising data, planning and interpreting data.

On the other hand, communication, interpersonal and selfmanagement skills were positively viewed, with writing being the main weakness in these three main skill areas. It seems then that despite success in the state school system as evidenced by Grade 8 final marks and OKS results, and despite being in the top 10 percentile of candidates who applied for the Erzurum school, the students showed weaknesses, before they began their work, in precisely the areas which the Erzurum project is targeting.

A factor analysis was carried out using the data from Stage 1 (subject exam plus general aptitude), Stage 2 (interview, musical aptitude, essay), OKS results, and the average score on skills for the 84 students in the summer program. Three main factors, accounting for $64 \%$ of the total variance, became apparent. The
Table 7

Rotated component matrix.

\begin{tabular}{llll}
\hline & \multicolumn{2}{l}{ Factors } & \\
\cline { 2 - 4 } & Entrance exam/OKS & Interview/essay/skills & Music/aptitude \\
\hline Entrance exam & .784 & & \\
OKS & .779 & .543 & \\
Interview & -.532 & .623 & \\
Essay & & .759 & .695 \\
Skills & & & .863 \\
Music & & & \\
Aptitude & & & \\
\hline
\end{tabular}

Extraction method: principal component analysis; rotation method: Varimax with Kaiser normalisation. A rotation converged in 5 iterations.

first connected the entrance examination and OKS scores; the second the interview, essay and skills assessment; and the third the musical aptitude and general aptitude, see Table 7 .

The interpretation of factors requires care but suggests a distinction between three factors. The first is the ability to succeed in examinations (the Erzurum entrance examination and the national OKS). The second is the ability to perform in higher order skills requiring communication, planning and organising, thinking on one's feet, and confidence to respond, either in interview or in writing. General aptitude would seem to be a third distinct factor. The factor analysis adds weight to the earlier argument that examination-taking abilities are separate from skills, and vindicates the choice of three types of assessment for entrance to the Erzurum school, particularly in view of its avowed aims.

The skills data is even more revealing when gender differences are taken into account. As already mentioned, the data were collected using a Likert-like scale for scoring. However, as it was criterion referenced, 4 being the best performance, it was thus amenable to statistical treatment using One Way ANOVA. The girls' performance was significantly better than boys on all the main skill categories in Table $6(p<.05)$. This may explain their superior, statistically significant, performance in the end of summer programme assessment.

\subsection{Attrition}

The attrition rate from places offered for the summer school (124 students) to registering for the summer programme (94) was $24 \%$, perhaps indicative of the innovative nature of the programme and the uncertainty this entails. Attrition continued between those registering (94 students) and those finishing the summer programme (84), albeit at a slower rate of $11 \%$, possibly due to candidates deciding to register for traditionally preferred high status schools. As the data show, there was a net reduction in the average OKS scores of the two groups which indicates that those with higher scores were tempted away to these schools. A further $10 \%$ attrition again continued into the first year of the project with 76 students coming back one year on for a second summer school at the end of their preparatory year.

\section{Discussion}

\subsection{Gender}

Families in the east and southeast of Turkey invest more in the education of their sons than their daughters. In the richer parts of the country, girls are given more opportunities, almost the same as those given to the boys. This is clearly seen from the figures. In the east, only $17 \%$ of the girls who attended compulsory schooling for primary education Grades 1-8 continue their schooling afterwards, to high schools or vocational schools. In the Aegean region, 
on the western seaboard, the figure is double: $34 \%$. The boy:girl ratio for high schools in the west of Turkey (Aegean) shows boys and girls not too far apart at 54\%:46\%. In the high schools of the east, there are almost two boys to every girl (64\%:36\%). The gender discrepancies continue into later life. Adult literacy across the whole country for males aged 15 years and over is $93.5 \%$, whereas that for females is 79.6\% (World Bank, 2005).

At the school in Erzurum, however, the situation is quite different as is seen in Table 3. To summarise, of the 867 Grade 8 students who applied, $49 \%$ were girls. After the first entrance exam, 226 students were selected, and 52\% of these were girls. Of these, 207 students took the Stage 2 exams, and 54\% were girls. Places were offered to 124 students, and 59\% of these were girls. Finally, 84 students entered the school at the start of the first year. By this time, the girls had dropped slightly, to $57 \%$ ( 48 girls and 36 boys).

Comparing the Erzurum school figures with national figures for the Eastern Region, it seems that girls in the east are educationally disadvantaged. Many families prefer their girls not to continue in formal education after completing elementary school, but to work within the family and community.

The Erzurum school is therefore already accomplishing one of its aims, namely to provide equality of opportunity to girls and boys. However, some girls were withdrawn from those selected for the Erzurum school after their success in the Stage 2 examinations: the number of girls dropped from 73 to 55 to $48=34.3 \%$. The number of boys dropped from 51 to $36=29.4 \%$. The reasons are not known.

Let us now look at the details of the entrance examination results in terms of gender. Table 3 shows the difference between girls and boys, with girls scoring higher than boys on all components of the Stage 2 tests. Clearly, girls from Erzurum can hold their own with their brothers in tests of academic achievement, and are presumably equally able to benefit from continued education.

The state high school selection examination at the end of Grade 8 , OKS, consists entirely of multiple-choice questions, which cover the main subjects taught in the primary school. The OKS marks given in Table 3 show that boys performed better than girls on both the arts and the science strands of the OKS examination, the difference in scores for boys and girls for the science strand (Sc/Ma) being statistically significant $(p<.05)$. On the other hand, we have already seen (Table 3 ) that girls performed better than boys on almost all the Erzurum school entry tests, especially at interview, musical aptitude and essay writing, as well as on the skills assessment carried out during the summer school.

Such results support the literature (Section 1.3.2) in suggesting that girls might be disadvantaged in OKS-style multiple-choice examinations, and that a different testing specification might be more appropriate and more inclusive of females. Further, when skills were considered over the eight-week summer school period, girls were assessed by their teachers as more competent in all skill categories (Table 6). Overall, then, the Erzurum selection examinations and the follow-up assessments gave girls more opportunity to display their abilities than is usual in selection tests in the country at this age. These tests will be kept, as being contributory to one of the aims of the Erzurum school.

\subsection{Socio-economic indicators}

The applicant profile for Stage 1 included all socio-economic groups. The results of the Stage 2 selection process similarly show a spread across all social groups. The children of those parents who may be regarded as being in the higher education or socioeconomic group achieved $27.5 \%$ of the places available. The children of those who may be regarded as members of groups with a lower educational or economic level achieved $29.8 \%$ of the available places. The civil servant group, with the largest number of applicants (29.5\%) gained $36.9 \%$ of the places. If, as argued above, the civil servant category includes families across the socioeconomic spectrum, then the aim of the project in capturing all walks of life in the student composition of the school was well and truly achieved.

Of note is the fact that the proportion of employed mothers for selected students was also higher, which supports earlier data from the east (Smits and Hoşgör, 2006).

Opening up educational access to the whole population in traditionally low attainment parts of the country was one of the project's aims. The project will continue to seek ways of extending inclusivity, including more contact and marketing amongst local schools, open days, concerts, and other ways to bring local people into school including the cultural programme, or wider promotion of the opportunity afforded to students through access to highreturn careers. It is clear also that parental occupation needs to be clarified in order to verify this conclusion through later cohorts.

\subsection{Skills}

Averaged data from the summer school skills study show that, overall, skill performance was weak in certain key areas deemed important in a constructivist approach to education. This was despite students being selected from amongst the top performing children in the school system, as seen by national percentile places in OKS results. The Turkish primary school system which favours multiple-choice and information-based examinations leads to the outcomes suggested by the Erzurum data: high scores in multiplechoice tests, but a relative dearth in thinking, research skills and communication skills.

The significantly large gender difference across all skills reverses the trend in OKS results, where boys out-performed girls as discussed above. Girls may be bearers of crucial skill sets, of relevance to higher levels in the education system, which are not detected by the national multiple-choice tests. Loading in the factor analysis suggests a link between skills, interview and essay performance, and appears to corroborate the skills data. The three share underlying traits such as ability to plan, think, communicate, and express ideas. We can say therefore, that the selection process took account of skills as they correlated with performance in interview and essay writing. Skills also appear to be linked to higher performance in language learning shown by the superior outcomes of girls during the summer school.

The number of large scale, easily graded, objective style tests is increasing with recent legislation in Turkey requiring national multiple-choice examinations to be extended to Grades 6 and 7. The aggregate score on these, given at the end of each of the last three years of primary education (Grades 6-8), will decide which students get a place in prestigious high schools. Cram schools (dershanes), already well used for those who can afford them, are now extending their business to even younger school children as a result.

The Erzurum school, in moving towards a more international model, faces the additional challenge of developing skill-based learning, but without a feeder school system promoting those skills. In addition, university access is, by law, through the national university entrance examination (ÖSS). The Erzurum students will need to meet the requirements of the ÖSS as well as the international examinations. Therefore, they will never be completely free of the multiple-choice environment unless international examinations are accepted towards university entrance.

\section{Conclusion}

The early stages of this study show that the Eastern Anatolian project is achieving its goals. The selection process for entry to the 
Erzurum school shows a more equitable male-female balance than is evident from the national figures for the region. There is also evidence that the project promotes access to families within a broad spectrum of representative occupations in Erzurum.

With regard to academic progress in school, the data show that the girls continue their earlier success and achieve on a par with or beyond the boys. They are capable of capitalising on their skill advantage, leading to an enhanced academic performance when compared to boys.

The research raises key concerns in terms of access to education where academic achievement, gender, family background and skills are important variables. The findings question once more the equity of multiple-choice testing for distinguishing talent and access; evidence here suggests such tests may exert a negative influence on gender selection for those continuing into high school. By extension, girls may be losing out in access to selective schools.

The study also suggests that selection using higher order skills contributes to enhanced academic performance in language learning later on. Ongoing research will tell whether these significant skill level differences are maintained throughout high school education and whether they can predict higher performance in international examinations. Early indications are that skill advantages are indeed maintained.

The data on occupational inclusivity is encouraging. However, the categorisation of family background in the continued research needs to distinguish categories more finely, as well as incorporate perceptions from recent family background studies. This will enable better correlation between a student's success in the school and his or her family's social resources, pecuniary and intellectual.

The development of the Eastern Anatolian project will be assisted by the formative contributions of the analysis of the data provided during the course of selection and students' progress at school. In addition, the understandings arising from the continuing study will ultimately provide evidence on the capacity of high school-focused innovations such as that discussed in this study to change traditional educational systems towards a more constructivist paradigm.

\section{References}

Aksit, N., 2007. Educational reform in Turkey. International Journal of Educational Development 27 (2), 129-137.

Aksoy, N., 2008. Multigrade schooling in Turkey: an overview. International Journal of Educational Development 28 (2), 218-228.

Arnot, M., Gray, J., James, M., Ruddock, J., Duveen, G., 1998. Recent Research on Gender and Educational Performance. The Stationery Office, London.

Aytaç, I., Rankin, B., 2004. Modernity, traditionality, and junior high school attainment in Turkey. Social Indicators Research 66, 267-282.

Australian Government Department of Education, 2009. Investing in our schools programme. Available at http://www.investinginourschools.deewr.gov.au/NR/ rdonlyres/789F3C98-9890-4897-9E68-4BADD57027EA/16257/2007StateGovernmentGuidelines.pdf.

Boocock, S.S., 1972. An Introduction to the Sociology of Learning. Houghton Mifflin, Boston.

Brannen, J., 2004. Working qualitatively and quantitatively. In: Seale, C., Gobo, J., Gubrium, J.F., Silverman, D. (Eds.), Qualitative Research Practice. Sage, London, pp. 312-326

Brint, S., 2006. Schools and Societies, second ed. Stanford University Press, Stanford.

Coleman, J.S., Campbell, E.Q., Hobson, C.J., McPartland, J., Mood, A.M., Weinfeld, F.D., York, R.L., 1966. Equality of Educational Opportunity. National Center for Educational Statistics, Washington, D.C.

Commission of the European Communities, 2006. Commission staff working document: Turkey 2006 progress report. Available at http://ec.europa.eu/enlargement/pdf/key_documents/2006/Nov/tr_sec_1390_en.ppd.

DCFS, 2009a. Academies. Available at www.standards.dfes.gov.uk/academies. Retrieved March 5, 2009.

DCFS, 2009b. DCSF: GCSE and equivalent results in England, 2007/08 (Revised). Available at http://dcsf.gov.uk/rsgateway/DB/SFR/s000826/index.shtml.

Douglas, J.W.B., 1964. The Home and the School. MacGibbon \& Kee, London.

Douglas, J.W.B., Ross, J.M., Simpson, H.R., 1968. All Our Future. Peter Davies, London.

Eğitim Sen, 2005. Demokratik Eğitim Kurultayı: Eğitim Hakkı. [Fourth Democratic Education Congress: Education Rights]. 1. Cilt. Eğitim Sen Yayınları, Ankara.

Elwood, J., 2005. Gender and achievement: what have exams to do with it? Oxford Review of Education 31 (3), 373-393.
Epstein, D., Elwood, J., Hey, V., Maw, J. (Eds.), 1998. Failing Boys? Issues in Gender and Achievement. Open University Press, Buckingham.

Erzurum Gazetesi, 2008. Erzurum'da öğretmen açı̆̆ı. Available at http://www.erzurumgazetesi.com.tr/default.asp?page=haber\&id=25081

Eurostat, 2007. Living conditions in Europe: Data 2002-2005. Available at http:// epp. eurostat.ec.europa.eu/cache/ITY_OFFPUB/KS-76-06-390/EN/KS-76-06390-EN.PDF

Forde, C. (Ed.), 2008. Tackling Gender Inequality: Raising Pupil Achievement. Dunedin Academic Press, Edinburgh.

Freebody, P., 2003. Qualitative Research in Education: Interaction and Practice. Sage, London.

Fretwell, D.H., Wheeler, A., 2001. Turkey: Secondary Education and Training. The World Bank, Washington, DC.

Gipps, C., Murphy, P., 1994. A Fair Test? Assessment Achievement and Equity. Open University Press, Buckingham.

Grossman, G.M., Sands, M.K., 2008. Restructuring reforms in Turkish teacher education: modernization and development in a dynamic environment. International Journal of Educational Development 28 (1), 70-80.

Gummesson, E., 2000. Qualitative Methods in Management Research. Sage, London.

Halsey, A.H., Heath, A.F., Ridge, J.M., 1980. Origins and Destinations: Family Class and Education in Modern Britain. Clarendon Press, Oxford.

Machin, S., McNally, S., 2006. Gender and Student Achievement in English Schools. Centre for the Economics of Education, LSE, London.

Marks, G.N., 2006. Are between- and within-school differences in school performance largely due to socio-economic background? Evidence from 30 countries. Educational Research 48 (1), 21-40.

MEB, 2003. Official Gazette, Milli Eğitim Bakanlığg İlköğretim Kurumları Yönetmeliği 27.08.2003/25212. Available at http://mevzuat.meb.gov.tr/html/ 225_0.html.

Milliyet, 2007. Birleștirilmiș sınıflarda 561 öğrenci okuyor. Available at http:// www.milliyet.com.tr/2007/01/03/guncel/gun03.hthl.

Nonoyama-Tarumi, Y., 2008. Cross-national estimates of the effects of family background on student achievement: a sensitivity analysis. International Review of Education 54, 57-82.

O'Dwyer, J., 2008. Formative Evaluation for Organisational Learning: A Case Study of the Management of a Process of Curriculum Development, vol. 8. Peter Lang, Anbieter.

OECD, 2001. Knowledge and Skills for life - First Results from PISA 2000. OECD, Paris.

OECD, 2002. PISA 2000: Technical Report. OECD, Paris.

OECD, 2003. World Competitiveness Report. OECD, Paris.

OECD, 2004. Learning for Tomorrow's World: First Results from PISA 2003. OECD, Paris.

OECD, 2008. OECD Programme for international student assessment (PISA). Available at http://www.pisa.oecd.org.

Orum, A.M., Feagin, J.R., Sjoberg, G., 1991. Introduction: the nature of the case study. In: Orum, A.M., Feagin, J.R., Sjoberg, G. (Eds.), A Case for the Case Study. The University of North Carolina Press, Chapel Hill.

PISA, 2007. PISA 2006: Science Competencies for Tomorrow's World, vol. 1: Analysis. OECD, Paris.

PISA, 2004. Learning for Tomorrow's World - First Results from PISA 2003. OECD, Paris.

Powney, J., 1996. Gender and Attainment. University of Glasgow, SCRE Centre.

PYP, 2008. What is the primary years programme (PYP)? Available at http:// www.ibo.org/pyp.

Radikal, 2007. 561 bin çocuk çağdışı sınıfta. http://www.radikal.com.tr/haber.php?haberno $=209030$.

Smits, J., Hoşgör, A.G., 2006. Effects of family background characteristics on educational participation in Turkey. International Journal of Educational Development 26 (5), 545-560.

Sirin, S.R., 2005. Socio-economic status and academic achievement: a meta-analytic review of research. Review of Educational Research 75 (3), 417-453.

Sahin, A., 2004. Qualitative assessment of the quality of Turkish elementary schools. In: World Bank, 2005. Sustainable Pathways to an Effective, Equitable, and Efficient Education System for Preschool through Secondary School Education. Education Sector Study, World Bank, Turkey.

Steinmayr, R., Spinath, B., 2008. Sex differences in school achievement: what are the roles of personality and achievement motivation? European Journal of Personality $22,185-209$.

Stobart, G., Elwood, J., Quinlan, J., 1992. Gender bias in examinations: how equal are the opportunities? British Educational Research Journal 18 (3), 261276.

Talim Terbiye Kurulu, 2005. İlköğretim 1-5.Sınıf Tanıtım El Kitabı. Devlet Kitapları Müdürlüğü Basımevi, Ankara.

Tinklin, T., 2003. Gender differences and high attainment. British Education Research Journal 29 (3), 307-324.

TÜIK, 2001. İllere göre GSYiH. Available at http://www.tuik.gov.tr//ulusalhesapapp/ ulusalhesap.zul?tur=2.

TÜIK, 2007. Türkiye İstatistik Yıllı̆̆ı 2006. Türkiye İstatistik Kurumu, Ankara.

TÜIK, 2008. Türkiye İstatistik Yıllığı 2007 . Türkiye İstatistik Kurumu, Ankara.

UNESCO, 2003. Gender and Education for All: The Leap to Equality: EFA Global Monitoring Report 2003/4. UNESCO, Paris.

UNDP, 2003. Human development indicators 2003. Available at http://hdr.undp.org/reports/global/2003/indicator/index.html.

UNDP, 2008. 2007-2008 report: Turkey. Available at http://hdrstats.undp.org/ countries/data_sheets/cty_ds_TUR.html. 
US Department of Education, 2009. Comprehensive school reform. Available at http://www.ed.gov/programs/compreform/2pager.html.

US Department of Education, 2002. Comprehensive school reform (CSR) program guidance. Available at http://www.ed.gov/programs/compreform/guidance/ guidance2002.pdf.

Ward, S. (Ed.), 2004. Education Studies. RoutledgeFalmer, London.

White, K.R., 1982. The relation between socio-economic status and academic achievement. Psychological Bulletin 91 (3), 461-481.

Wong, K.-C., Lam, Y.R., Ho, L.-M., 2002. The effects of schooling on gender differences. British Educational Research Journal 28, 827-843.
World Bank, 2006. Loan agreement. Available at http://www-wds.worldbank.org/ external/default/WDSContentServer/WDSP/ECA/2006/07/05/ 4DE7A6F3326495492852571F00553AB1/2_0/Rendered/PDF/L4767.pdf.

World Bank, 2005. Turkey Education Sector Study. World Bank, Washington, DC.

Yin, R.K., 1994. Case-study Research: Design and Methods. Sage, London.

Yurdugül, H., Aşkar, P., 2004. Ortaögretim kurumlari ögrenci seçme ve yerlestirme sinavinin ögrencilerin yerlesim yerlerine göre diferansiyel madde fonksiyonu açisindan incelenmesi. Hacettepe Üniversitesi Egitim Fakültesi Dergisi 27, 268-275. 